\title{
高生に関する生理学的研究補遺一水溶液の $\mathrm{pH}$ K就て
}

\author{
そ の 2 \\ Neutral redに依る植物細胞生体染色
}

岡山大学:医学部生理学:教室（主任：林教授）

講師岡田勝喜

[昭和 29 年 9 月 17 日炎稿]

\section{I 緒 論}

藷者はは光に brilliant (re!l bue による

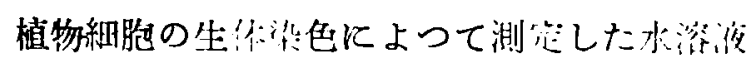

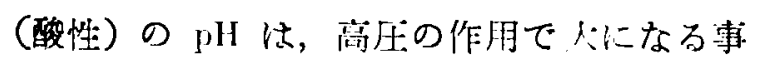
実を報告したが，今回は努しど同㥞にして，

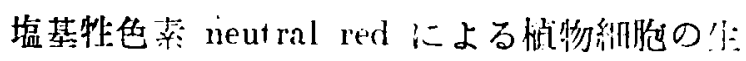
体染仙によつて，问压の作用による小游 $\mathrm{pH}$ の変化を調へた。

\section{II 実験材料及び方法}

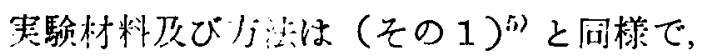

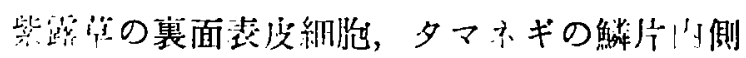

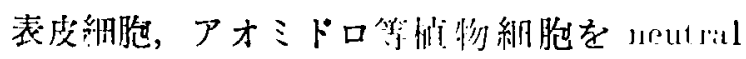
$\operatorname{red}(以 下$ ‥R. と略記する) 水溶液に洼した

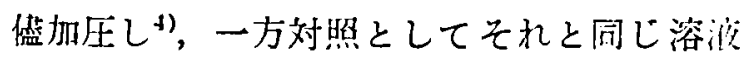

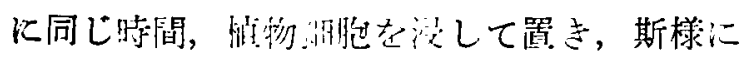
して得た加圧細胞（以下 $\mathrm{P}$ と略記）と対照細

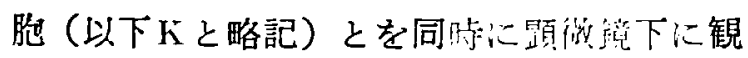
察し, 綊胞膛, 液胞等の染色状態その他を比 輍する，染色の濃淡その他の比較は程度に心 して+,一の記号で表した。

neutral red の弯色域は pH 6.6〜8.0の間で 㤸ら黄になる.

\section{III 実験成績}

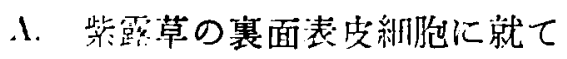

1. $\mathrm{pH}$ の買る二つの N. R. 水溶液の比較 水道水及び蒸溜水の $\mathrm{pH}$ は, 水素イオン浱 度測定用東洋渍紙で測ると，夫々6.6〜 6.8及 で5.8〜6.2である. 斯る $\mathrm{pH}$ の異る二つの N.R. 水溶液は色調が相湋し, 勿諭酸は洂，

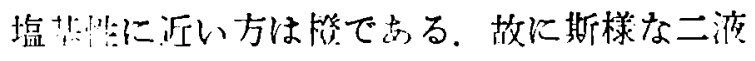

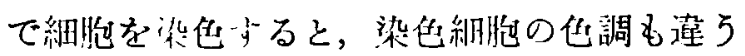
事もむるが，生体染色では多くの場合区別し

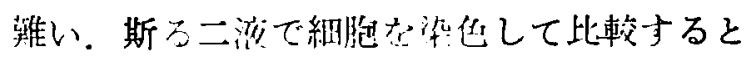

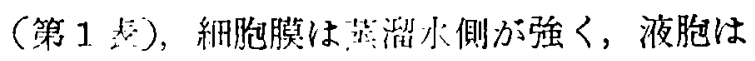

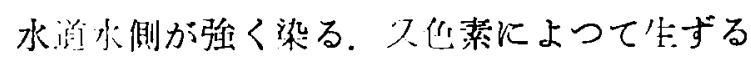

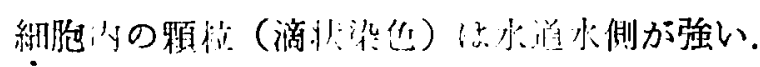

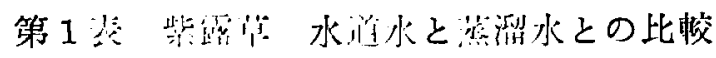

\begin{tabular}{|c|c|c|c|c|c|c|}
\hline \multirow{2}{*}{$\begin{array}{l}\text { 㭙阔 } \\
\text { (分) }\end{array}$} & \multicolumn{2}{|c|}{ 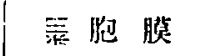 } & 液 & 胞 & 顆 & 柆 \\
\hline & 承通水 & 薙溜水 & 水道小 & 灌溜水 & 水䦽皮 & 溜溜水 \\
\hline 10 & + & + & $H$ & + & $H$ & + \\
\hline 20 & + & $H$ & t: & + & H & + \\
\hline 25 & + & $H$ & + & + & H & + \\
\hline 30 & + & $H$ & $H$ & + & it & + \\
\hline 80 & + & $H$ & H & + & & \\
\hline
\end{tabular}

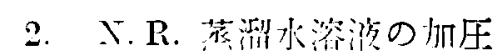

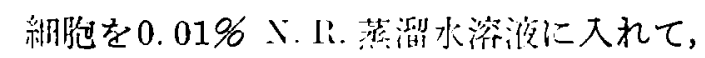
500 1500 笑原，10２0分間加圧し，対照と 比輬した（第 2 住）.

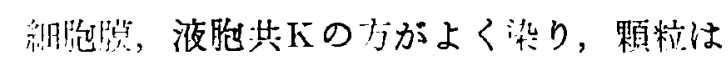

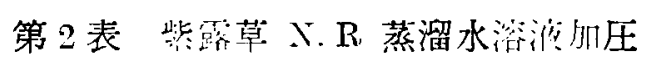

\begin{tabular}{|c|c|c|c|c|c|c|c|}
\hline \multirow{2}{*}{$\begin{array}{l}\text { E 力 } \\
\text { (気压) }\end{array}$} & \multirow{2}{*}{$\begin{array}{l}\text { 時間 } \\
\text { (分) }\end{array}$} & \multicolumn{2}{|c|}{ 細胞膜 } & \multirow{2}{*}{$\frac{\text { 液 }}{\text { 加照 }}$} & \multirow{2}{*}{$\begin{array}{c}\text { 胞 } \\
x_{1}^{1} \text { 照 } \\
(\mathrm{K})\end{array}$} & \multirow{2}{*}{ 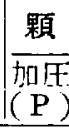 } & \multirow{2}{*}{ 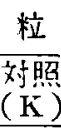 } \\
\hline & & $\begin{array}{l}\text { क्त } \\
(P)\end{array}$ & 刘照 & & & & \\
\hline 1500 & 10 & + & + & + & $+(H)$ & + & \pm \\
\hline 1000 & 20 & $H$ & m & + & H & H & + \\
\hline 1000 & 15 & + & H & + & $H$ & \# & + \\
\hline 1000 & 10 & \pm & + & \pm & + & & \\
\hline 1000 & 10 & + & ". & + & H & \pm & \pm \\
\hline 500 & 20 & + & $+(H)$ & + & H & & \\
\hline 500 & 20 & + & $+(+)$ & - & + & \pm & \pm \\
\hline 500 & 10 & 4 & H & $+(+t)$ & + & + & - \\
\hline
\end{tabular}


Pの方疒多い。

B. タマホギ鱗片の内皮納胞に就て

1. $\mathrm{pH}$ の異る二つの N. R. 水溶没の比较 $0.01 \%$ N.R. の水道水溶液 と蒸溜水溶液 とをA. 1 と同様にして比較した（第 3 表）. 即ち細胞膜は酸性:の強い) 液胞は塩基性汇近い方（水道小）が濃く染る。 又トノプラスト宁離（以下 $\mathrm{T}$ 分離と略記）は 水道水が強く起る。

第 3 琴 タマネギ 水道水と蒸溜水との比較

\begin{tabular}{|c|c|c|c|c|c|c|}
\hline \multirow{2}{*}{$\begin{array}{l}\text { 時間 } \\
(\text { 分) }\end{array}$} & \multicolumn{2}{|c|}{ 細 胞 膜 } & 液 & 胞 & \multicolumn{2}{|c|}{$\begin{array}{l}1 \text { 分ブラス } \\
\text { 卜分離 }\end{array}$} \\
\hline & 水道水 & 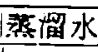 & 水道水 & 溜水 & 水道 & 跡溜水 \\
\hline 10 & + & $H$ & H & + & H & \pm \\
\hline 20 & + & $H$ & $H^{\prime}$ & - & H & + \\
\hline 30 & + & H & H & \pm & H & + \\
\hline 40 & + & $H$ & $H$ & - & m & \pm \\
\hline
\end{tabular}

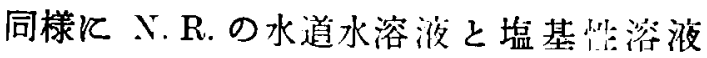
（pH7.6～7.8）とを比輷すると（第 4 表A）, 液 胞で塩基性液側が少し溜く染る他，余り差が ない. 又 N.R.の水道水浴液と $\mathrm{pH} 8.0 \sim 8.8$ の塩基性水溶液を比恔すると（第 4 表 B)，級 胞膜では差がないが，液胞は塩基性水溶液側 が強く染り， T分離も同じ側が稍強い。

第 4 表A. タマネキ 水道水と塩基临液 (pH 7.6 7.8) との比䡥

\begin{tabular}{|c|c|c|c|c|c|c|}
\hline \multirow{2}{*}{$\begin{array}{l}\text { 時間 } \\
\text { (分) }\end{array}$} & \multicolumn{2}{|c|}{ 絊 胞 膜 } & 液 & 胞 & \multicolumn{2}{|c|}{ 分離 } \\
\hline & 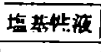 & 水道水 & 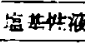 & 水道水 & 坦基性没 & 永道水 \\
\hline 10 & + & + & H & $H$ & + & + \\
\hline 10 & + & + & $H$ & + & + & + \\
\hline 20 & + & + & H & 世 & $H$ & \# \\
\hline 20 & + & + & $H$ & + & + & H \\
\hline 30 & + & + & H & + & $H(H+)$ & $H$ \\
\hline
\end{tabular}

第 4 表 B. タマネギ 水道水と塩基性液 (pH 8.2 8.8) との比䡴

\begin{tabular}{|c|c|c|c|c|c|c|}
\hline \multirow{2}{*}{$\begin{array}{l}\text { 時間 } \\
\text { (分) }\end{array}$} & \multicolumn{2}{|c|}{ 細 胞 膜 } & 液 & 胞 & \multicolumn{2}{|c|}{$\begin{array}{l}\text { 今分プラス } \\
\text { 分離 }\end{array}$} \\
\hline & 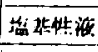 & 水道水 & 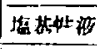 & 水道水 & 㨫基娃被 & 水道水 \\
\hline 10 & \pm & \pm & + & \pm & $+(H)$ & + \\
\hline 20 & + & + & $H$ & + & + & + \\
\hline
\end{tabular}

2. N.R. 蒸澹水溶液の加压 紐胞を $0.01 \%$ N.R. 蒸溜水溶液に浸した滥

200１500 気压，10３0 分間加圧して対照と 比較した（第 5 表 $\mathrm{A}$ ）．即ち細胞膜は $\mathrm{K} か ゙$ 稍 胎く染り，液胞は 1000 気压以上で $\mathrm{P} ， \mathrm{~K}$ 江殆 んぞ差がないが，500気庄以下では Pが強く 染る。 $\mathrm{T}$ 分離す500気圧以下で $\mathrm{P}$ が強い。

第 5 表A．タ、ネギ N.R. 蒸溜水溶液加圧

\begin{tabular}{|c|c|c|c|c|c|c|c|}
\hline \multirow{2}{*}{$\begin{array}{c}\text { 王力 } \\
(\text { (经氏) }\end{array}$} & \multirow{2}{*}{$\mid \begin{array}{l}\text { 時間 } \\
\text { (分) }\end{array}$} & \multicolumn{2}{|c|}{ 細胞 膜 } & \multicolumn{2}{|c|}{ 液 胞 } & \multicolumn{2}{|c|}{ 卜分ブラス } \\
\hline & & $(\mathrm{m})$ & $\begin{array}{l}\text { 対照 } \\
(\mathrm{K})\end{array}$ & $\begin{array}{l}\text { 加压 } \\
(\mathrm{P})\end{array}$ & $\begin{array}{l}\text { 对照 } \\
(\mathrm{K})\end{array}$ & $\begin{array}{l}\text { 妿保 } \\
(\mathrm{P})\end{array}$ & $\begin{array}{l}\text { 対照 } \\
(K)\end{array}$ \\
\hline 1500 & 10 & + & + & + & $T$ & \pm & $T$ \\
\hline 1000 & 20 & + & + & + & + & H & \# \\
\hline 1000 & 10 & + & $+(H)$ & + & $\pm(+)$ & 冊 & + \\
\hline 500 & 30 & + & + & + & $+(H)$ & + & \# \\
\hline 500 & 20 & + & $+(\because)$ & $+(H)$ & + & $+(H)$ & \# \\
\hline 500 & 10 & + & + & + & \pm & H & + \\
\hline 200 & 30 & + & H & $+(+1)$ & + & H & + \\
\hline 200 & 10 & + & + & $+(H)$ & \pm & H & \pm \\
\hline
\end{tabular}

加压維胞をボンべから出して後, 対照の紐 胞之同じ条件下に置き，10 分及び 20 分後両 者を比較すると（後遗作用）(第 5 表 B)，細

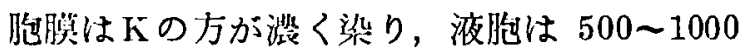

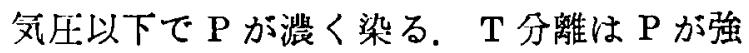
w.

第 5 表 B. タマネキ 後遺作用

\begin{tabular}{|c|c|c|c|c|c|c|c|}
\hline \multirow{2}{*}{\multicolumn{2}{|c|}{$\mid \begin{array}{c}\text { 在力 } \\
\text { (氮 } \\
\text { 压) }\end{array}$}} & \multicolumn{2}{|c|}{ 緇胞膜 } & \multicolumn{2}{|l|}{ 液 } & \multicolumn{2}{|c|}{$\begin{array}{l}\text { 卜分プラス } \\
\text { 分離 }\end{array}$} \\
\hline & & ( & $\begin{array}{l}\text { 扵照 } \\
(\mathrm{K})\end{array}$ & $\begin{array}{l}\text { 加压 } \\
(\mathbf{P})\end{array}$ & (K) & 加压 & $\begin{array}{l}\text { 対照 } \\
(\mathrm{K})\end{array}$ \\
\hline & 1000,20 & + & 4 & + & + & $H$ & + \\
\hline & 100010 & + & $+(H)$ & + & + & $+(+)$ & \pm \\
\hline & 50030 & + & + & H & H & + & $H$ \\
\hline 分 & 50020 & + & $+(H)$ & $H$ & + & H & $+(H)$ \\
\hline & 50010 & + & $+(H)$ & + & \pm & $H$ & + \\
\hline & 20030 & + & $+(+t)$ & + & \pm & + & \pm \\
\hline & 200.10 & + & + & $+(H)$ & + & H & + \\
\hline & 100020 & + & $+(+t)$ & + & + & $H$ & + \\
\hline$N$ & 100010 & + & $+(H)$ & + & \pm & HI & + \\
\hline & 50030 & $H$ & H & H & + & + & + \\
\hline 分 & 50020 & H & $H(H t)$ & H & $\pm(+)$ & $H$ & + \\
\hline & 50010 & + & $+(H)$ & + & $\pm(+)$ & $H$ & + \\
\hline & 20030 & + & $+(+)$ & + & \pm & H & + \\
\hline & 20010 & + & + & $+(H)$ & + & H & H \\
\hline
\end{tabular}

3. $\mathrm{N}$. R. 水道水溶液の加圧

$0.01 \%$ N. R. 水道水溶液に細胞を浸した侁, 
500 1500 気圧，10－30 分間加圧し，対照と 比較した（第 6 表A）。即ち䄄胞膜は P，Kに 差がないが，液胞は 500 気压，30分以上の加 圧でKが稍強く染り， $\mathrm{T}$ 分離は 1000 気压以上 でKが，500気压以下で Pが強い。

第 6 表A. タマネギ N.R. 水道水溶液加圧

\begin{tabular}{|c|c|c|c|c|c|c|c|}
\hline \multirow{2}{*}{$\frac{\text { E力 }}{\text { 気死 }}$} & \multirow{2}{*}{$\begin{array}{l}\text { 時 } \\
\text { 間 } \\
\text { 分 }\end{array}$} & \multicolumn{2}{|c|}{ 細胞 膜 } & \multicolumn{2}{|l|}{ 液 } & \multicolumn{2}{|c|}{ 分プラス } \\
\hline & & ( & ( & 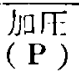 & $\begin{array}{l}\text { 対照 } \\
(\mathrm{K})\end{array}$ & $\begin{array}{l}\tan 1 \\
(\mathbf{P})\end{array}$ & 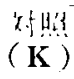 \\
\hline 1500 & 10 & + & + & + & \# & - & H \\
\hline 1000 & 20 & + & + & + & + & + & $H$ \\
\hline 1000 & 10 & + & + & + & $+(H)$ & $H$ & +11 \\
\hline 500 & 30 & + & + & + & $+(t+)$ & $+(H)$ & + \\
\hline 500 & 20 & + & + & H & H & $+(H)$ & + \\
\hline 500 & 10 & + & + & $H$ & H & + & + \\
\hline
\end{tabular}

上記 2. の場合之同様，加压後 10 及び 20 分 経過して雨者を比輍与ると（第6 6 济 $\mathrm{B}$ )，細

第 6 表 B. 夕マホギ 後造作用

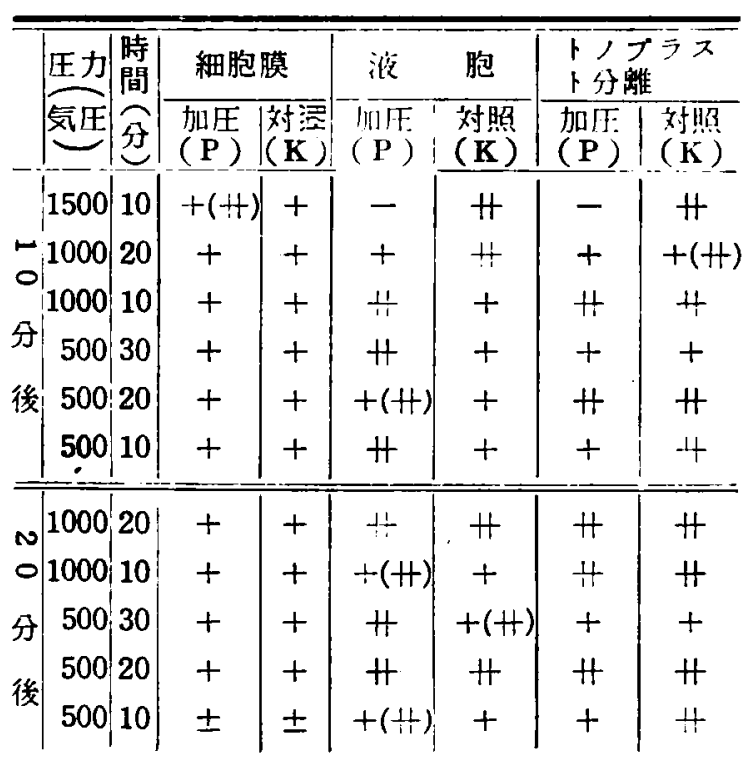

胞膜では差がないが，液胞は1000気压20分以 上の扣压ではКが，1000気圧，10 宁以下では

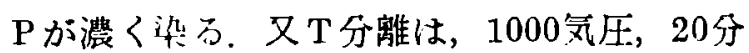
以上の加压で下が強い。

\section{4. $\quad$ N. R. 塩基牲水溶液の加圧}

細胞を $\mathrm{N} . \mathrm{R}$. 塩基性水溶液 $(\mathrm{pH} 8.3 \sim 8.8)$ に人れて 200〜1000気厈，10〜30分間加圧し， 対照の細胞と比饾した（第 7 婊），細胞膜で は浊者の差がないが，液胞は 500 気圧以上で

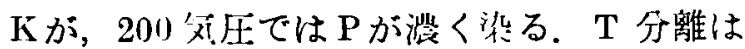
1000 気压でKが，200父压では $\mathrm{P} か ゙$ 強い。

第て表 タマ京ギ X.R. 垣基性水溶液 (pH 8.3〜子.8) の加压

\begin{tabular}{|c|c|c|c|c|c|c|}
\hline \multirow{2}{*}{ 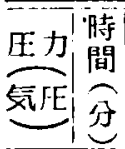 } & \multicolumn{2}{|c|}{ 細 胞 膜 } & \multicolumn{2}{|l|}{ 液 } & \multicolumn{2}{|c|}{$\begin{array}{l}\text { 卜分フス } \\
\text { 分離 }\end{array}$} \\
\hline & $\begin{array}{l}(\mathrm{P}) \\
(\mathrm{P})\end{array}$ & (K) & $\begin{array}{l}\text { 㔔厓 } \\
(\mathbf{P})\end{array}$ & (対照 & $\begin{array}{l}\text { 加在 } \\
\text { (P) }\end{array}$ & $\begin{array}{l}\text { 対照 } \\
(\mathrm{K})\end{array}$ \\
\hline $1000 \quad 10$ & \pm & \pm & \pm & + & \pm & + \\
\hline 100010 & \pm & \pm & + & H & + & $+(H)$ \\
\hline 50030 & + & + & $+(H)$ & + & & \\
\hline 50020 & \pm & \pm & \# & H & & \\
\hline 50010 & \pm & \pm & + & $+(+t)$ & + & + \\
\hline 20030 & + & H & $\pm(+)$ & \pm & $+(+1)$ & + \\
\hline 200 & + & + & $+(\#)$ & \pm & H & \pm \\
\hline
\end{tabular}

\section{5. 緗胞の死後染色}

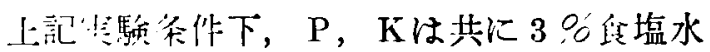
で原形質分離が起る。即ち細胞は生きて居る。 今度は $1 \% \mathrm{KCX}$ 水港液又は熱湯で処理して 死堿させた細胞（3告食塩水で分離しない） で同様な実験を行つた。斯る細胞を $0.01 \%$ N.R. の水道水洸使と蒸溜水溶液とに浸して 比較すると（第 8 表A），染色の色調は水道

第 8 表 A. タマネキ 死後染色水道水と蒸溜水の比輍

\begin{tabular}{|c|c|c|c|c|c|c|c|c|c|c|c|c|}
\hline & \multirow{2}{*}{$\begin{array}{c}\text { 時 間 } \\
\text { (分) }\end{array}$} & \multicolumn{2}{|c|}{ 胞 } & \multicolumn{2}{|l|}{ 液 } & \multicolumn{2}{|c|}{ 核 } & \multicolumn{2}{|c|}{ 色 } & \multicolumn{3}{|c|}{ 調 } \\
\hline & & 水道 水 & 蒸溜水 & 水道水 & 䇰溜 水 & 水道 水 & 登溜 水 & 水 & 水 & 蒸 & 馏 & 水 \\
\hline 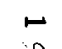 & 10 & \pm & \pm & + & + & $\pm(+)$ & + & & & & & \\
\hline$\frac{\pi}{5}$ & 20 & $H$ & $H$ & + & $+(H)$ & $\pm(+)$ & $\pm(+)$ & 稍 & 橙 & 稍 & & 赤 \\
\hline$\Omega$ & 30 & $H$ & $H$ & H & H & \pm & \pm & 稍 & 橙 & 稍 & & 赤 \\
\hline$z$ & 40 & + & + & $H$ & $H$ & + & + & 稍 & 橙 & 稍 & & 赤 \\
\hline 熱 & 10 & $\pm(+)$ & $\pm(+)$ & - & - & + & + & & & & & \\
\hline & 20 & + & + & $\pm(+)$ & $\pm(+)$ & +1 & H & 硝 & & 稍 & & 赤 \\
\hline & 30 & $H$ & $H$ & + & + & H & H. & & & & 赤 & \\
\hline 绪 & 40 & $H$ & $H$ & H & H & H & H & & & & 赤 & \\
\hline
\end{tabular}


水が登，蒸溜水が赤で，かなり明確に区別出 来る. 此の色調の相違の為, 染色の濃淡は比 較し難いが，概してその浱淡には法が諰めら れない，死滅細胞を $0.01 \%$ N. R. 蒸溜水溶液 に浸して 200１500 気压，10３0分間加压し，
対照と比較すると（第 8 帮 $\mathrm{B}$ ），染色の濃度 には荅んど差がないが，色調はPが橙，Kが 赤の傾向がある。但し其の差は必ずしす明確 ではない。

第 8 表 B. タマネギ 死後染色 N.R. 蒸溜水溶液の加圧

\begin{tabular}{|c|c|c|c|c|c|c|c|c|c|c|c|c|}
\hline & \multirow{2}{*}{ 压気压) } & \multirow{2}{*}{ (分) } & \multirow{2}{*}{\multicolumn{2}{|c|}{ 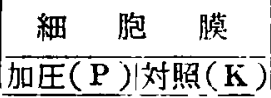 }} & 液 & 胞 & \multirow{2}{*}{\multicolumn{2}{|c|}{$\frac{\text { 核 }}{}$}} & \multicolumn{2}{|c|}{ 色 } & \multicolumn{2}{|c|}{ 調 } \\
\hline & & & & & 加压(P) & 対照 (K) & & & $\overline{\text { 加圧 }}$ & $(\mathrm{P})$ & 対照 & $3(\mathrm{~K})$ \\
\hline \multirow{5}{*}{ 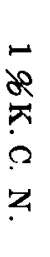 } & 2000 & 10 & + & + & + & + & \pm & \pm & & & & \\
\hline & 1500 & 20 & H & H & + & $+(+\#)$ & + & + & & & & \\
\hline & 1000 & 10 & + & + & + & + & + & + & & & & \\
\hline & 500 & 20 & H & H & $+(+1)$ & + & + & + & & & & \\
\hline & 200 & 15 & Ht & H & + & $+(++)$ & + & + & 稍 & 橙 & 稍 & 赤 \\
\hline \multirow{3}{*}{ 熱 } & 1500 & 25 & H & H & + & H & + & $H$ & & & & \\
\hline & 1000 & 20 & + & + & + & + & + & + & 稍 & & 稍 & \\
\hline & 1000 & 10 & \pm & \pm & + & + & & & & & & \\
\hline \multirow{3}{*}{ 哭 } & 500 & 30 & H & H & + & $+(H)$ & H & \# & 稍 & & 稍 & \\
\hline & 500 & 10 & H & $+(+)$ & + & + & + & + & & & & \\
\hline & 200 & 30 & H & \# & + & + & H & H & & 橙 & & 赤 \\
\hline
\end{tabular}

C. アオミドロに就て

1. $\mathrm{pH}$ の显る二つの X. R. 水溶液の比较 アオミドロを $0.001 \%$ N.R.の器溜水溶液 と水道水溶液とに10２0分間浸して比較する と(第 9 奏), 細胞膜は蒸溜水側が搌く, 滩胞 は水道水側が稍濼く染る。

第 9 突アオミドロ 水道水と 蒸溜水との比軑

\begin{tabular}{|c|c|c|c|c|}
\hline \multirow{2}{*}{$\left.{ }^{\text {分 }}\right)^{\text {間 }}$} & 細 & 膜 & 液 & 胞 \\
\hline & 水道水 & 喜溜水 & 水道水 & 慜涸水 \\
\hline 10 & \pm & + & + & + \\
\hline 10 & \pm & + & + & $+(H)$ \\
\hline 20 & \pm & + & $+(H)$ & + \\
\hline 20 & \pm & + & $+(H)$ & + \\
\hline
\end{tabular}

2. X.R. 蒸溜水溶液の加压

アオミドロを $0.001 \%$ N. R. 蒸溜水溶液に 浸した㦈 500〜1500気圧，10２0分間加圧し て対照と比較した（第10表）.

細胞膜では両者の差が殆んどないが，液胞 はKが強く染る．特に 1000 気圧以上で著し W.
第 10 㤗 アオミドロ N.R. 蒸溜水 滛滥の加圧

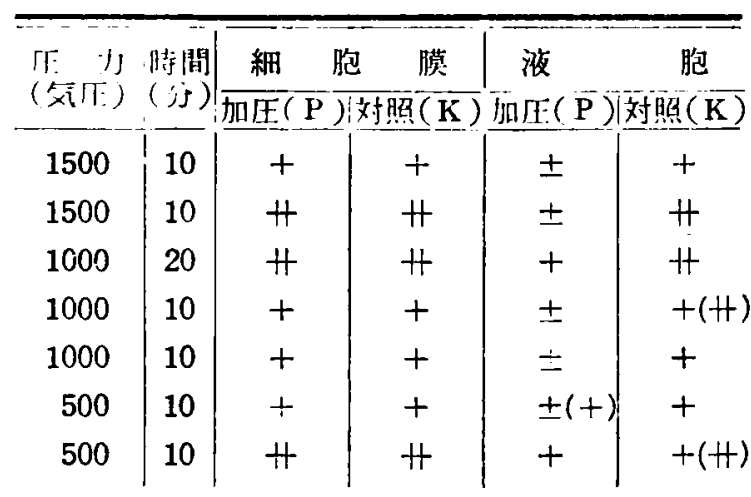

\section{IV 考察並に総活}

塩基性色素で植物細胞の生体染色を行う時， その色素溶液が酸性の時は綳胞脱が，中性又

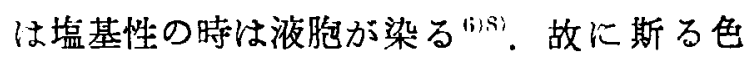
菜溶液に植物緗胞を浸した睢加圧すると，そ の $\mathrm{pH}$ が高压の作用で変化するなら，それに 忍して植物細胞の細胞膜或は液胞の染色状態 が違つて来る筈である、斯る方法で調べた結 果 $(そ の 1)^{5)}$ では, brilliant cresyl blue (塩 基性色素）水溶液は高压の作用により塩基性 
飞傾く事が明になつた。

以下（その1）と同様にして行つた neuitral red による奖験の成緽を枪討して見よ5. 先づN.R.の蒸溜水溶被と水道水溶液とを比 較すると，普通㓩者は酸牲，後者は中牲に近 い. 柴路草 (第 1 表)，タマネギ（第 3 表），

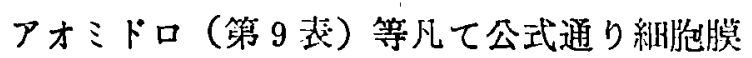
は蒸溜水側, 液胞は水道水倒が強く染る。斯 る方法でる二つの液体の $\mathrm{pH}$ の大小を比較す る事は出来る，但し溶液が中性附近では，細 胞脱が染色し難いので，細胞膜による二洨の 比較は困難になる（第 4 表，A，B）. 尚色素 による細胞内顆粘の発生（滴状染色）(紫露 草）及びトノプラスト分離（タマネギ）は何 れも水道水側が強い，併しその差が溶液 $\mathrm{pH}$ の相䧺に基ずくか否かは明でない。

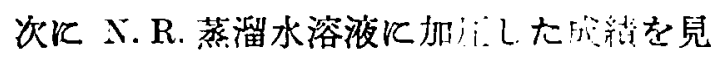

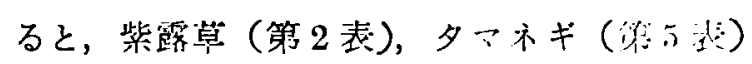
の場合，䋑脆膜では P は $\mathrm{K}$ に比し染仙がす

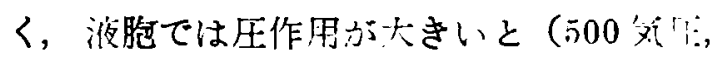

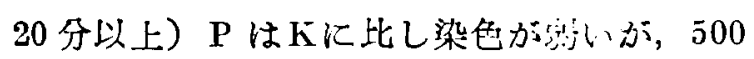
気圧，10分以下ではPの方が稍強い。此の染 色状態から見ると, 高压仗よる水溶液 $\mathrm{pH} の$ 変化の方向は決定出来ないか，次のよ5に考 えれば理解し易い，即ち液胞に比し細胞膜は 生命的要素の少い組織であるから，高左の二 次的影響が小さいであろ5。吕に対し高王に よる液胞の染色変化は, 細胞自体が強く変化 して表われた像であるう。液胞の加圧（500 気圧，10分以下）で，それが塭基性飞傾く（P がKに比し強く染る）のは, 此の程度の圧力 では細胞自体の変化飞基く影響が弱く，水溶

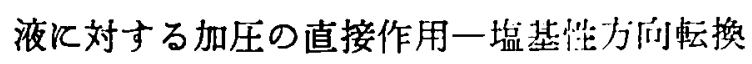
のみが表面佰出たものであるう。アオミドロ の場合 (第 10 表), 細胞膜は P， Kに殆んど 差がなく, 液胞は何れる $\mathrm{P}$ 側が染色乙難い。 之はアオミドロの細胞膜の染色状態がその厚 さの微少なる為観察し難い事及び細胞自身が

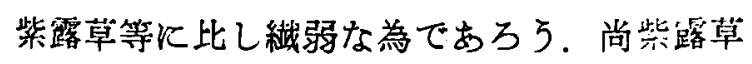
の顆粒発生及びタマネギのトノプラスト分離 は，斯る現象の強弱が $\mathrm{pH} の$ 差に基くとすれ

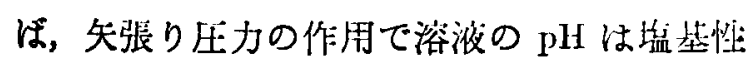

に傾く事になる，但し此の現象は著者》の研 究から推察すると，一部は高左による膜邀過 性の艺進によると思われるが，笑験 A. 1 及 び B. 1 を兒てる一部は $\mathrm{pH}$ その他の相犊に 原因があろ 5 . 久 N.R. 兴溜水溶液の加庄後 遺作用を見ると（第 5 表 B ），細胞膜及び液 胞染出（500父庄，20 分以下）又卜ノプラス 卜分晟は何れる $\mathrm{P}$ 例が強度である，之を加圧 直後の観察成績比べと，P，Kの差が液 胞て大である（細胞脱は同程度である），之 は細胞膜が比輍的物理化学的反心近いる を現わすのに，液胞は生命的な複雑な現象を 表現する事によるのであるう。

次に N.R.の水道水或は塩基性水溶液の加 瓜成績を見ると（第 6 表A，第 7 表），細胞膜 染色は $\mathrm{P} ， \mathrm{~K}$ に殆んど差がなく，液胞染色は 500 気生以上で $\mathrm{P}$ 側が弱く, 以下では朔火 $\mathrm{P}$ 側が瓷い。トノプラスト分離も液胞と略同様 である，然等は胕述のように水溶液が一層塩

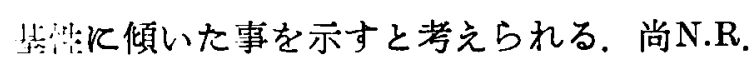
水道水溶液の加圧後遭作用 (第 6 表 B), 上

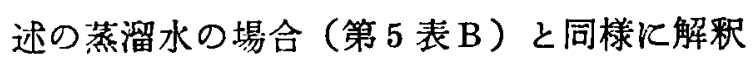
される。

更に細胞の死後染色は色素が単飞細胞内に 拡散する事により起るのであるから，第 8 表

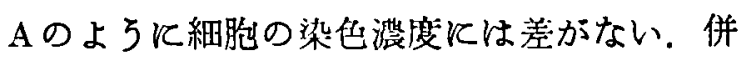
し色調は $\mathrm{pH}$ の相違により赤 (酸性), 橙 (塩 基性）の差が認められる。死隇細胞飞加庄し ても(第 8 表 B ) P，K飞染色濃度の差がな い事は上記理由で当然と思われるが，第 8 表 $\Lambda$ 程色調の差が $\mathrm{P} ， \mathrm{~K}$ 間に認められないのは, その変化が蒸溜水と水道水の瑟和もないのに よるのか，或は除圧して（その瞬間高压によ

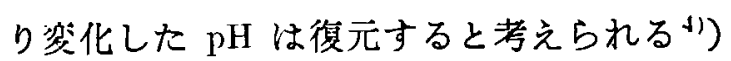

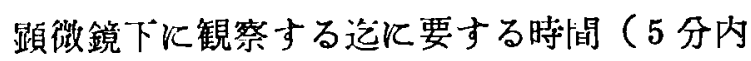
外）で色調の差がなくなるによるのか明らか でない.

以上のように考㒵ると $\mathrm{pH}$ 5〜9位の N. R. 水溶没は压作用で, $\mathrm{pH}$ は增加の方向へ移動 すると思われる，著者》の研究傜よると弱電 解質は强電解質に比し，高圧の作用で解離度 の增大が著しい，往つて塩基性出尛 N.R.は 
高王の作用で OH イオンを多量に遊背し $\left(\mathrm{ROH} \rightarrow \mathrm{R}^{+}+\mathrm{OH}^{-}\right)$，而多多くの埸合大気庄 下，水溶液が酸性を示す原因となる小量の絈 䉓解質の高压によるHイオンの增加を上まわ ると推測されるので，高压により $\mathrm{N}$. R. 水溶 液の $\mathrm{pH}$ は增大の方向へ移﨡寸ると理解され る。故に高庄に上る水溶液 $\mathrm{pH}$ の峦化飞対し ては，大気压下の其の水溶液 $\mathrm{pH}$ よりも，圧 作用で解離すべき $\mathrm{H}$ 或は $\mathrm{OH}$ イオンの多寡が 問題となる。而も弱电船質は強電解啠飞比し， 高压の作用で遥かに強く解離度を增すから, 一般的に見れば水溶液の $\mathrm{pH}$ の高圧による変 化は，其の溶淮中に含まれる弱電解質の量と 質とにより決定されるであるう.

\section{$\mathrm{V}$ 結 論}

neutral red（塩基性色素）による植物細胞
の生体染色を利用して高压火よる水溶液 $\mathrm{pH}$ の変化を調べ次の結果を得た。

1. 細胞膜を指標とすると neutral red 水 溶液の $\mathrm{pH}$ は高圧飞より塩基性傾く。

๖. 液胞を指標とすると neutral red 水溶 液の $\mathrm{pH}$ は在作用が強いと酸性汇傾き，压作 用が弱いと塩基性に傾く，併し液胞は高圧飞 よる影響が大きいから，圧作用の強い時の液 胞の染色変化は一次的 $\mathrm{pH}$ 変化の指標になら ない。

3. 即ち neutral red 水溶液の $\mathrm{pH}$ 滈压

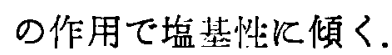

4. 一般に水溶液の $\mathrm{pH}$ の高压による变化 は，高圧により解離すべき $\mathrm{H}$ 或は $\mathrm{OH}$ イオン の量により決定される。

擱筆するに当り終始御想篤なる御指導と御校期を 賜つた恩師林教授に対し哚く感謝の意を表す。

献

5) 著者 本誌 (その一).

6) 相見：細胞生理学研究法. 164 .

7) 著者：本誌. 第五編.

8）北大植物生理学敉室：植物生理学実習. 32 .

Department of 1 Physiology, Okayama University Medical School.

(Director Prof. Dr. K. Hayasi)

\section{Physiological Studies of Hydrostatic High Pressure.}

\section{Supplement II. On pH Found in a Neutral red Solution}

By

\section{Katuki Okada}

In rase any living staining of plant cell (Trades cantia, Allium cepa, Spirogyra) should be observed as $\mathrm{pH}$-indicator, the $\mathrm{pH}$ of neutral red solution increases, owing to high pressure. 